\title{
Fabrication of Biporous Low-crystalline Apatite Based on Mannitol Dissolution from Apatite Cement
}

\author{
Shinya TAJIMA ${ }^{1}$, Yuji KISHI ${ }^{1}$, Makoto ODA ${ }^{1,2}$, Michito MARUTA ${ }^{2}$, Shigeki MATSUYA ${ }^{2}$ \\ and Kunio ISHIKAWA ${ }^{2}$ \\ ${ }^{1}$ Japan Institute for Advanced Dentistry, Shiba TK building 4F, 1-8-25 Shiba, Minatoku, Tokyo 105-0014 Japan \\ ${ }^{2}$ Department of Biomaterials, Faculty of Dental Science, Kyushu University, 3-1-1 Maidashi, Higashiku, Fukuoka 812-8582, \\ Japan \\ Corresponding author, Kunio Ishikawa E-mail:ishikawa@dent.kyushu-u.ac.jp
}

Received July 6, 2006/Accepted July 25, 2006

\begin{abstract}
Biporous (macro- and microporous) calcium phosphate gains much attention as a bone substitute material because of its large surface area and that it improves cell penetration. In the present study, we evaluated the feasibility of biporous, lowcrystalline apatite based on dissolution of mannitol from self-setting apatite cement (Biopex ${ }^{\circledR}$ ). Mannitol - known as a biocompatible, easily dissolved monosaccharide alcohol - was recrystallized to obtain larger crystals. It was crushed with pestle and mortar, sieved to obtain crystals which passed through a $500-\mu \mathrm{m}$ mesh but which remained against a $300-\mu \mathrm{m}$ mesh, and then used as porogen. Although Biopex ${ }^{\circledR}$ containing $60 \mathrm{wt} \%$ mannitol was not able to be taken out of the mold, addition of mannitol caused no initial setting inhibition to Biopex ${ }^{\circledR}$ if the amount was $40 \mathrm{wt} \%$ or less. Similarly, transformation to apatitic product was confirmed when the apatite cement was immersed in $0.9 \%$ saline kept at $37^{\circ} \mathrm{C}$ for seven days. The set mass became low-crystalline, biporous apatite with approximately $60 \%$ porosity.
\end{abstract}

Key words: Apatite cement, Porous, Mannitol

\section{INTRODUCTION}

Self-setting reaction and resulting apatite formation of $\alpha$-tricalcium phosphate ( $\alpha$-TCP: $\left.\alpha-\mathrm{Ca}_{3}\left(\mathrm{PO}_{4}\right)_{2}\right)$ was reported by Monma and Kanazawa in $1976^{1)}$. They reported that $\alpha$-TCP set to form calcium-deficient hydroxyapatite with $\mathrm{Ca} / \mathrm{P}$ molar ratio of 1.5 when $\alpha$-TCP was hydrated in water at $60-100^{\circ} \mathrm{C}$ and $\mathrm{pH}$ between 8.1 and 11.4. Although this was the initial finding of apatite cement, its long setting time prevented its clinical use for a long period.

In 1986, Brown and Chow reported that a mixture of tetracalcium phosphate (TTCP: $\mathrm{Ca}_{4}\left(\mathrm{PO}_{4}\right)_{2} \mathrm{O}$ ) and dicalcium phosphate anhydrous (DCPA: $\mathrm{CaHPO}_{4}$ ) set within approximately 30-60 minutes at physiological temperature and formed apatitic product when mixed with an aqueous solution ${ }^{2,3)}$. Based on their initial findings, many types of apatite cement have since been studied and developed including Biopex ${ }^{\circledR 4-33)}$.

Apatite cements show excellent tissue response and good osteoconductivity since its composition is apatitic after setting $6,7,12-14,21,23,25)$. In contrast to the sintered apatite which is not replaced by bone but instead keeps its shape in the bone defect, apatite cements are reported to be replaced by bone although the process takes time $e^{6,12,23)}$. The mechanism of apatite cements' replacement by bone is not fully clarified yet. Nonetheless, it is believed that low crystallinity may be one of the factors that facilitates bone replacement since low-crystalline apatite shows more solubility than high-crystalline apatite.
Set apatite cement is a porous material with approximately $30 \%$ porosity $^{10,32)}$, and this porosity contributes favorably to the replacement of apatite cement by bone. However, apatite cement produced at the usual mixing condition gives rise to microporosity, and thus no cell penetration can be expected. It has been demonstrated that macropores $(>100 \mathrm{~mm})$ allowed ingrowth of bone tissue with haversian systems and facilitated osteoconduction in the case of sintered calcium phosphates ${ }^{34-39)}$. In the present study, therefore, the feasibility of biporous (macro- and microporous), low-crystalline apatite was evaluated based on dissolution of mannitol from self-setting apatite cement $\left(\right.$ Biopex $\left.^{\circledR}\right)$.

\section{MATERIALS AND METHODS}

Biopex $^{\circledR}$ was kindly donated by Mitsubishi Materials (Tokyo, Japan). Powder form of mannitol $\left(\mathrm{CH}_{2} \mathrm{OH}\right.$ $\left.(\mathrm{CH}(\mathrm{OH}))_{4} \mathrm{CH}_{2} \mathrm{OH}\right)$ ) obtained commercially (Nacalai, Tesque, Kyoto, Japan) was recrystallized for both purification and size regulation. It was saturated in a mixed solution of methanol-water $(1: 1 \mathrm{vol})$ at 70 ${ }^{\circ} \mathrm{C}$, and then filtered and cooled to room temperature. Obtained crystals were crushed with mortar and pestle and passed through an electromotion sieve. Crystals that passed through $500-\mu \mathrm{m}$ mesh, but which remained against $300-\mu \mathrm{m}$ mesh, were used as porogen (Fig. 1).

Mannitol crystals thus prepared were added to the powder phase of Biopex ${ }^{\circledR}$, so that mannitol 
content in the powder phase became 20 , 40, or $60 \mathrm{wt}$ $\%$. Then, the powder phase was mixed with the liquid phase of Biopex ${ }^{\circledR}$. Although the manufacturer recommended mixing the liquid phase with powder phase at $0.36 \mathrm{~mL} / \mathrm{g}$, this mixing ratio resulted in a cement paste that was too wet. This was because the surface area of mannitol crystals was too small compared with the powder phase of Biopex ${ }^{\circledR}$. Thus, mixing was done such that the weight of liquid phase and weight of powder phase excluding mannitol crystals became $0.36 \mathrm{~mL} / \mathrm{g}$. The liquid and powder phases were mixed using a glass slab and spatula, and then the cement paste was placed in a split mold (6 $\mathrm{mm}$ in diameter $\times 3 \mathrm{~mm}$ in height). Both ends of the mold were then covered by glass plates and clamped. The paste was pre-hardened by storing in an incubator kept at $37^{\circ} \mathrm{C}$ and $100 \%$ relative humidity for 24 hours, and after which taken out of the mold and immersed in $0.9 \%$ saline at $37^{\circ} \mathrm{C}$ for an additional seven days.

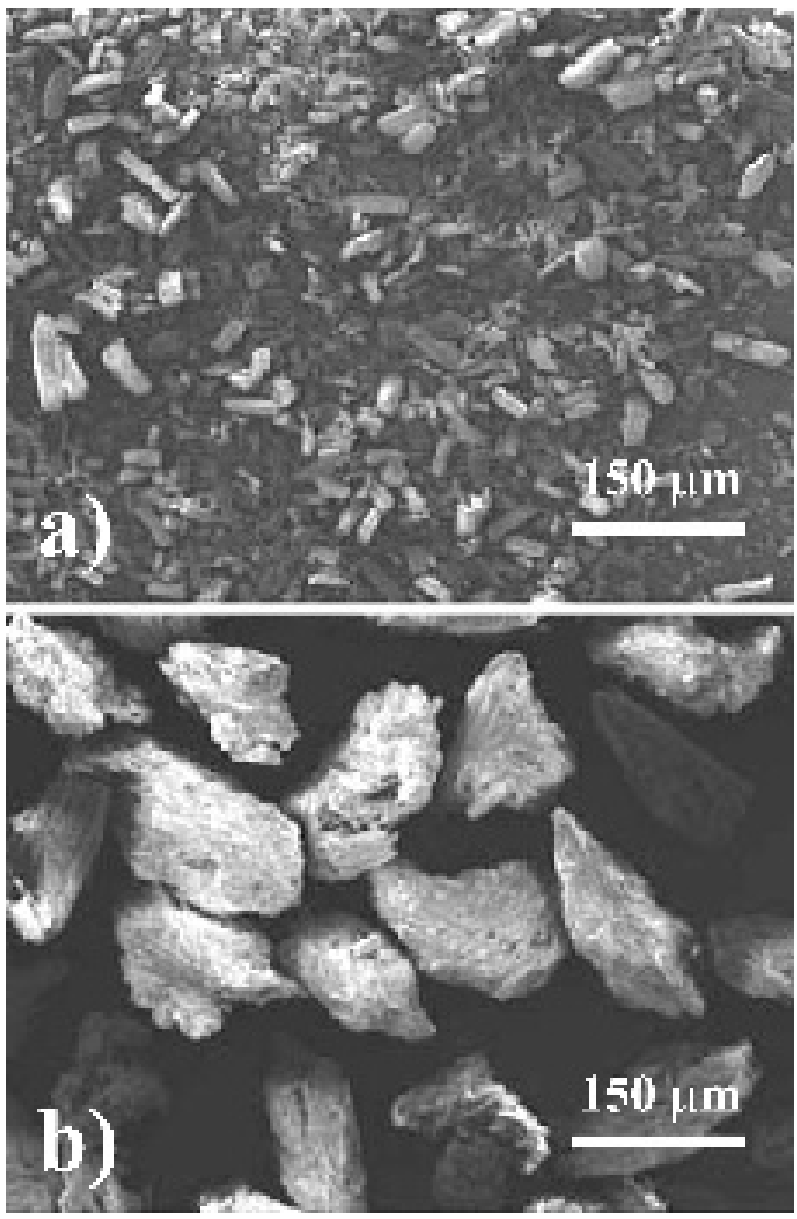

Fig. 1 Scanning electron microscopic images of mannitol (a) Commercially obtained mannitol; (b) Recrystallized and sieved mannitol. Mannitol crystals that passed through $500-\mu \mathrm{m}$ but remained against $300-\mu \mathrm{m}$ mesh were used as porogen.
After keeping in the $0.9 \%$ saline for seven days, the specimens were washed with distilled water, dried, and supplied for scanning electron microscopic observation (JSM 5400LV, JEOL, Tokyo, Japan). The cement was mounted on metal holders prior to gold coating, and after which SEM observations were carried out.

Biopex $^{\circledR}$ composition was identified by means of X-ray diffraction (XRD) analysis. The specimens were ground into fine powders and characterized by XRD. XRD patterns of the specimens were recorded with a vertically mounted diffractometer system (RINT 2500V, Rigaku, Tokyo, Japan) using countermonochromatized $\mathrm{CuK} \alpha$ radiation generated at $40 \mathrm{kV}$ and $100 \mathrm{~mA}$. The samples were scanned from $3^{\circ}$ to $60^{\circ}$ in a continuous mode $\left(2.0^{\circ} 2 \theta / \mathrm{min}\right)$, and the intensity was recorded at $0.02^{\circ}$ intervals. Note that only XRD patterns of $20-45^{\circ}$ were presented since no important peaks were found outside this scan range.

Porosity of the apatite cement was calculated by measuring the weight and volume of the cement ${ }^{32)}$. Porosity was calculated based on the assumption that cement composition was apatitic and that the density of apatite was $3.16 \mathrm{~g} / \mathrm{cm}^{3}$. The density was the average value for at least four specimens.

For statistical analysis, one-way factorial ANOVA and Fisher's PLSD method as a post-hoc test were performed using the software, "Stat View 4.02" (Abacus Concepts Inc., Berkeley, California).

\section{RESULTS AND DISCUSSION}

Although the initial setting reaction would be completed after keeping in an incubator at $37^{\circ} \mathrm{C}$ with $100 \%$ relative humidity for 24 hours, Biopex ${ }^{\circledR}$ that contained 60 wt $\%$ of mannitol crystals was not able to be taken out of the mold. This was caused by an excess content of mannitol crystals in the Biopex ${ }^{\circledR}$ composition, thus inhibiting the set Biopex ${ }^{\circledR}$ to keep its shape. Therefore, the following studies focused on Biopex ${ }^{\circledR}$ containing 40 wt\% or less mannitol crystals. When Biopex ${ }^{\circledR}$ contained 40 wt\% or less mannitol, the specimens could be easily taken out of the mold and no significant differences in the handling property were observed.

Fig. 2 shows the typical SEM pictures of the fractured surface of Biopex $^{\circledR}$ containing $0 \% \quad(\mathrm{a}, \mathrm{c})$ and 40 wt\% (b, d) mannitol after being kept in $0.9 \%$ saline at $37^{\circ} \mathrm{C}$ for seven days. Fig. 2 (a) shows the lower magnification of Biopex ${ }^{\circledR}$ containing no mannitol. Only small pores that might be introduced during the mixing procedure were seen on its surface. In contrast, large pores were found in the case of Biopex ${ }^{\circledR}$ containing 40 wt $\%$ mannitol (Fig. 2(b)). These pores were thought to be formed by the dissolution of mannitol. At this stage, no remaining mannitol was observed indicating that mannitol dissolved completely within seven days. At the higher 

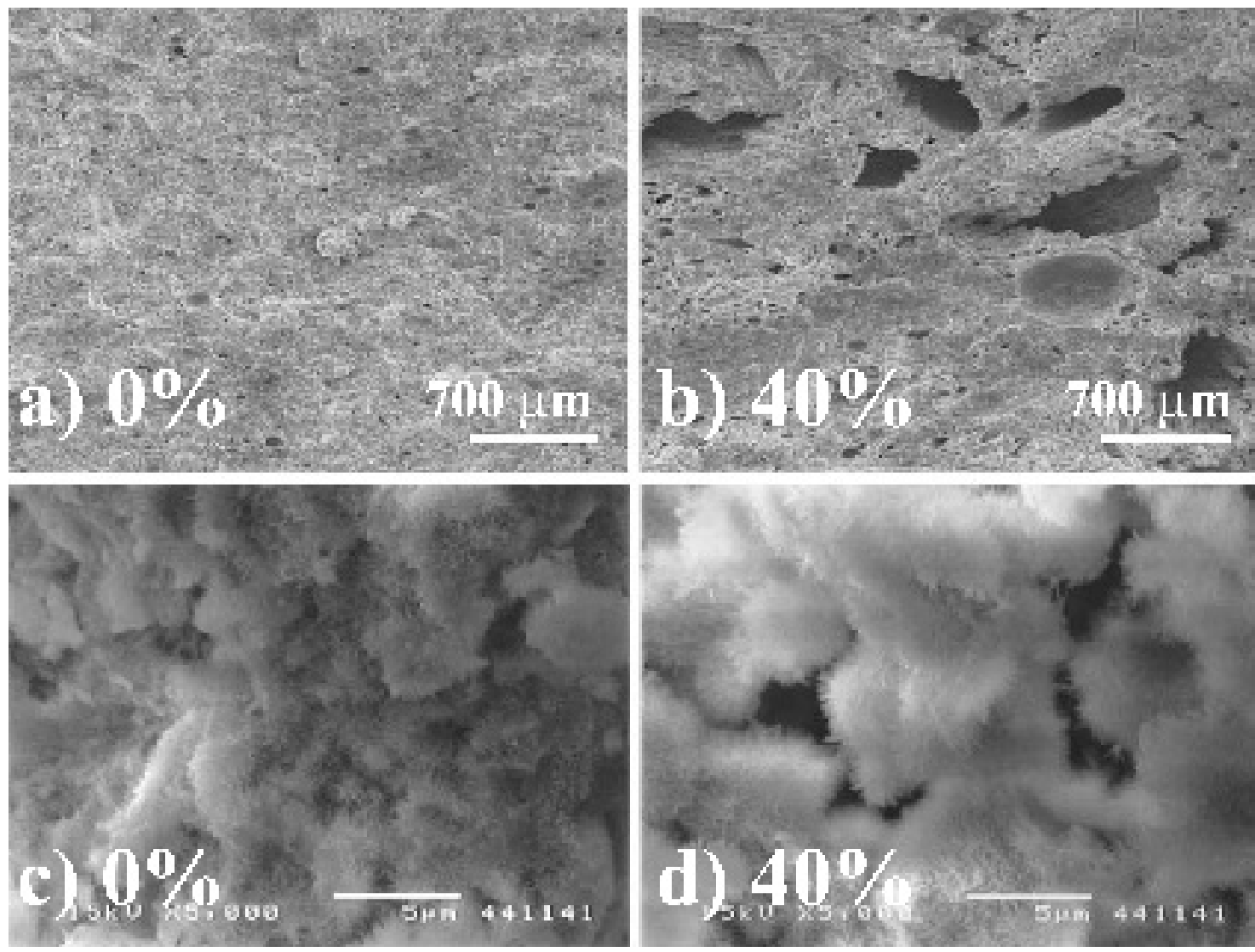

Fig. 2 Fractured surface of Biopex ${ }^{\circledR}$ containing $0 \%$ (a, c) or 40 wt\% (b, d) mannitol after being kept in an incubator at $37^{\circ} \mathrm{C}$ and $100 \%$ relative humidity for 24 hours, followed by being immersed in $0.9 \%$ saline at $37^{\circ} \mathrm{C}$ for 7 days. Lower magnification (a, b) reveals that macropores are also formed for Biopex ${ }^{\circledR}$ containing $40 \mathrm{wt} \%$ mannitol. Higher magnification (c, d) reveals that needle-like crystals form clusters and micropores.

magnification (c, d), it is seen that set Biopex ${ }^{\circledR}$ was composed of clusters of needle-like crystals that are typical of apatite, and that these needle-like crystals formed micropores.

Fig. 3 summarizes the porosity of Biopex as a function of added mannitol. Porosity of Biopex ${ }^{\circledR}$ containing no mannitol was $33.0 \pm 2.5 \%$. It can be seen that the porosity of Biopex ${ }^{\circledR}$ increased linearly with the amount of added mannitol to reach $59.8 \pm 3.4 \%$ when $40 \mathrm{wt} \%$ of mannitol was added. Although the difference in porosity between Biopex ${ }^{\circledR}$ containing 40 wt $\%$ and 0 wt $\%$ mannitol was $26.8 \%$, it was a reasonable difference since Biopex ${ }^{\circledR}$ itself was a porous material with $33.0 \%$ porosity. It should be noted that the microporosity of Biopex ${ }^{\circledR}$ is also important for the formation of micropores since interconnected micropores may be used when mannitol is dissolved and released from Biopex ${ }^{\circledR}$.

As can be seen from the XRD patterns, apatite formed by the setting reaction of Biopex ${ }^{\circledR}$ was of a lower crystallinity. For Biopex ${ }^{\circledR}$ to be replaced by bone, Biopex ${ }^{\circledR}$ needs to be resorbed by osteoclasts. Low-crystalline apatite is generally preferred for

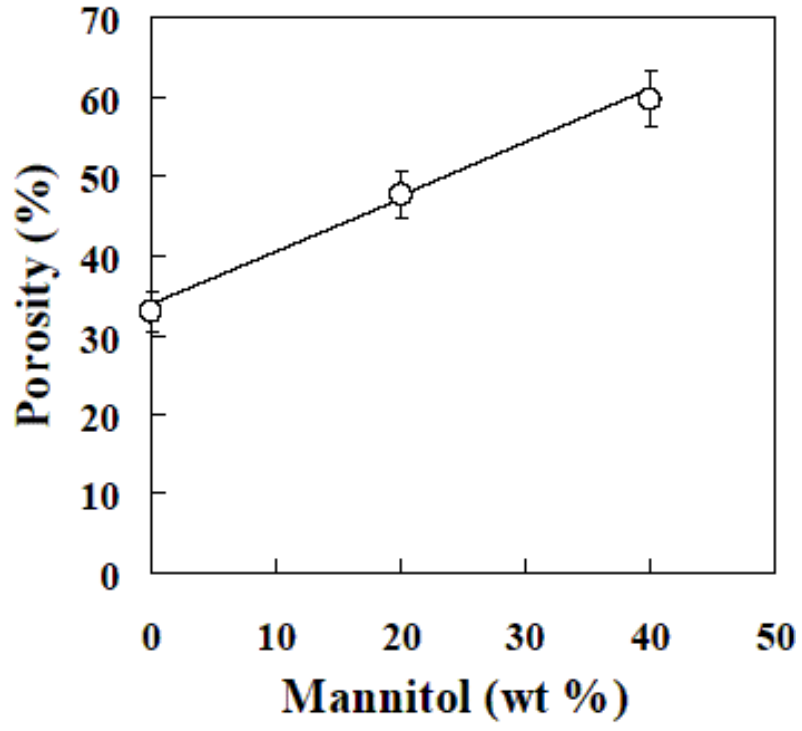

Fig. 3 Effect of added mannitol on the porosity of Biopex ${ }^{\circledR}$. Porosity of Biopex ${ }^{\circledR}$ increases linearly with added mannitol. 
osteoclast resorption. Hence, low-crystalline apatite formed by the setting reaction of Biopex $^{\circledR}$ would seem to expedite the replacement of Biopex ${ }^{\circledR}$ by bone.

Although the addition of mannitol was found to be an effective means to yield macropores, it is well known that organic materials inhibit apatite formation. Thus, mannitol added to Biopex ${ }^{\circledR}$ may inhibit apatite formation in the set cement. To find out whether added mannitol did indeed inhibit apatite formation in Biopex ${ }^{\circledR}$, XRD analysis of Biopex ${ }^{\circledR}$ composition was carried out. Fig. 4 summarizes the XRD patterns of Biopex $^{\circledR}$ containing 0, 20, and 40 wt $\%$ mannitol after being kept in $0.9 \%$ saline at 37 ${ }^{\circ} \mathrm{C}$ for seven days. XRD patterns of the powder phase of Biopex ${ }^{\circledR}$ and apatite are also shown for comparison. Basically, no differences in apatite formation were found regardless of the amount of added mannitol. Unreacted $\alpha$-TCP was also found regardless of the amount of added mannitol. Crystallinity of apatite - which can be judged by the width of the peak - was also the same regardless of the amount of added mannitol.

Although the mechanism of apatite formation has not been clarified in the present study, it could be said that added mannitol dissolved quickly from Biopex ${ }^{\circledR}$ and caused no inhibitory effects on the transformation and resulting setting reaction of Biopex ${ }^{\circledR}$ - if the amount was 40 wt $\%$ or less. As a result of mannitol dissolution, we could successfully fabricate biporous, low-crystalline apatite. Moreover,

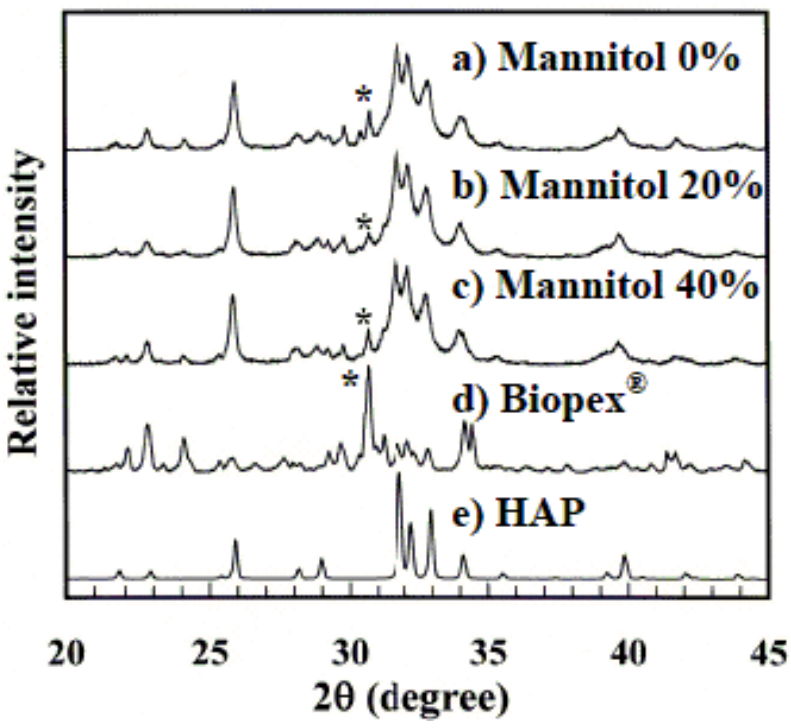

Fig. 4 Typical X-ray diffraction patterns of Biopex ${ }^{\circledR}$ containing $0-40 \mathrm{wt} \%$ mannitol in its powder phase when pre-hardened in an incubator kept at $37^{\circ} \mathrm{C}$ and $100 \%$ relative humidity for 24 hours and immersed in $0.9 \%$ saline at $37^{\circ} \mathrm{C}$ for 7 days. XRD patterns of the powder phase of Biopex ${ }^{\circledR}$ and apatite were also shown for comparison. $\alpha$-TCP $(*)$. the porosity of Biopex ${ }^{\circledR}$ containing $40 \mathrm{wt} \%$ mannitol was approximately $60 \%$.

In light of the favorable findings of this initial study, further study will be conducted to obtain more details on the fabrication of biporous, lowcrystalline apatite by adding $40 \mathrm{wt} \%$ or less mannitol to Biopex ${ }^{\circledR}$.

\section{ACKNOWLEDGEMENTS}

This study was supported in part by a Grant-in-aid for Scientific Research from the Ministry of Education, Science, Sports and Culture, Japan.

\section{REFERENCES}

1) Monma $\mathrm{H}$, Kanazawa $\mathrm{T}$. The hydration of $\alpha$ tricalcium phosphate. Yogyo-Kyokai-Shi 1976; 84: 209213.

2) Brown WE, Chow LC. Paste as mineralizers and cements, US Patent No.4, 612,053 (1986).

3) Brown WE, Chow LC. A new calcium phosphate, water-setting cement. In: Cements research progress, American Ceramic Society, Westerville, Ohio, 1987, pp.351-379.

4) Ishikawa K, Takagi S, Chow LC, Ishikawa Y. Properties and mechanisms of fast-setting calcium phosphate cements. J Mater Sci: Mater Med 1995; 6: 528-533.

5) Ishikawa $K$, Miyamoto $Y$, Kon $M$, Nagayama $M$, Asaoka K. Non-decay type fast-setting calcium phosphate cement: composite with sodium alginate. Biomaterials 1995; 16: 527-532.

6) Constantz BR, Ison IC, Fulmer MT, Poser RD, Smith ST, VanWagoner M, Ross J, Goldstein SA, Jupiter JB, Rosenthal DI. Skeletal repair by in situ formation of the mineral phase of bone. Science 1995; 267: 17961799 .

7) Kurashina K, Kurita H, Kotani A, Takeuchi H, Hirano M. In vivo study of a calcium phosphate cement consisting of alpha-tricalcium phosphate/dicalcium phosphate dibasic/tetracalcium phosphate monoxide. Biomaterials 1997; 18: 147-151.

8) Yokoyama A, Yamamoto S, Kawasaki $\mathrm{T}$, Kohgo $\mathrm{T}$, Nakasu M. Development of calcium phosphate cement using chitosan and citric acid for bone substitute materials. Biomaterials 2002; 23: 1091-1101.

9) Driessens FCM, Boltong MG, Bermudez O, Planell JA, Ginebra MP, Fernandez E. Effective formulations for the preparation of calcium phosphate bone cements. J Mater Sci: Mater Med 1994; 5: 164-170.

10) Ishikawa K, Asaoka K. Estimation of ideal mechanical strength and critical porosity of calcium phosphate cement. J Biomed Mater Res 1995; 29: 1537-1543.

11) Ishikawa $K$, Miyamoto $Y$, Takechi $M$, Ueyama $Y$, Suzuki K, Nagayama M, Matsumura T. Effects of neutral sodium hydrogen phosphate on setting reaction and mechanical strength of hydroxyapatite putty. J Biomed Mater Res 1999; 44: 322-329.

12) Ooms EM, Wolke JG, van de Heuvel, MT, Jeschke, B, Jansen JA. Histological evaluation of the bone re- 
sponse to calcium phosphate cement implanted in cortical bone. Biomaterials 2003; 24: 989-1000.

13) Oome EM, Egglezos EA, Wolke JG, Jansen JA. Softtissue response to injectable calcium phosphate cements. Biomaterials 2003; 24: 749-757.

14) Dickson KF, Friedman J, Buchholz JG, Flandry FD. The use of BoneSource hydroxyapatite cement for traumatic metaphyseal bone void filling. J Trauma 2002; 53: 1103-1108.

15) Yetkinler DN, Goodman SB, Reindel ES, Carter D, Poser RD, Constantz BR. Mechanical evaluation of a carbonated apatite cement in the fixation of unstable intertrochanteric fractures. Acta Orthop Scand 2002; 73: $157-164$.

16) Arriaga MA, Chen DA. Hydroxyapatite cement cranioplasty in translabyrinthine acoustic neuroma surgery. Otolaryngol Head Neck Surg 2002; 126: 512517.

17) Saito $\mathrm{T}$, Kin $\mathrm{Y}$, Koshino $\mathrm{T}$. Osteogenic response of hydroxyapatite cement implanted into the femur of rats with experimentally induced osteoporosis. Biomaterials 2002; 23: 2711-2716.

18) Welch RD, Berry BH, Crawford K, Zhang H, Zobitz M, Bronson D, Krishnan S. Subchondral defects in caprine femora augmented with in situ setting hydroxyapatite cement, polymethylmethacrylate, or autogenous bone graft: biomechanical and histomorphological analysis after two-years. J Orthop Res 2002; 20: 464-472.

19) Ooms EM, Wolke JG, van der Waerden JP, Jansen JA. Trabecular bone response to injectable calcium phosphate (Ca-P) cement. J Biomed Mater Res 2002; 61: $9-18$

20) Baker SB, Weinzweig J, Kirschner RE, Bartlett SP. Applications of a new carbonated calcium phosphate bone cement: early experience in pediatric and adult craniofacial reconstruction. Plast Reconstr Surg 2002; 109: 1789-1796.

21) Miyamoto $Y$, Ishikawa $K$, Takechi $M$, Yuasa $M$, Kon M, Nagayama M, Asaoka K. Non-decay type fastsetting calcium phosphate cement: setting behavior in calf serum and its tissue response. Biomaterials 1996; 17: $1429-1435$.

22) Tanaka S, Kishi T, Shimogoryo R, Matsuya S, Ishikawa K. Biopex ${ }^{\circledR}$ acquires anti-washout properties by adding sodium alginate into its liquid phase. Dent Mater J 2003; 22: 301-312.

23) Miyamoto $Y$, Ishikawa K, Takechi M, Toh T, Yoshida Y, Nagayama M, Kon M, Asaoka K. Tissue response to fast-setting calcium phosphate cement in bone. $\mathrm{J}$ Biomed Mater Res 1997; 37: 457-464.

24) Takechi M, Ishikawa K, Miyamoto Y, Nagayama M, Suzuki K. Tissue responses to anti-washout apatite cement using chitosan when implanted in the rat tibia. J Mater Sci: Mater Med 2001; 12: 597-602.

25) Ueyama $\mathrm{Y}$, Ishikawa $\mathrm{K}$, Mano $\mathrm{T}$, Koyama $\mathrm{T}$, Matsumura T, Suzuki K. Initial tissue response to anti-washout apatite cement in the rat palatal region: comparison with conventional apatite cement. J Biomed Mater Res 2001; 55: 652-660.

26) Ishikawa K, Miyamoto $\mathrm{Y}$, Toh $\mathrm{T}$, Yuasa $\mathrm{T}$, Ito $\mathrm{A}$, Nagayama M, Suzuki K. Fabrication of Zn containing apatite cement and its initial evaluation using human osteoblastic cells. Biomaterials 2002; 23: 423-428.

27) Oda M, Kaku T, Ookubo A, Matsuya S, Ishikawa K. The effects of hardening environment on the conversion to apatite and the mechanical strength of apatite cement. J J Soc Oral Impl 2003; 16: 400-408.

28) Fukase Y, Eanes ED, Takagi S, Chow LC. Setting reactions and compressive strength of calcium phosphate cement. J Dent Res 1990, 69: 1852-1856.

29) Miyamoto $Y$, Ishikawa $K$, Fukao $H$, Sawada $M$, Nagayama M, Kon M, Asaoka K. In vivo setting behavior of fast-setting calcium phosphate cement. Biomaterials 1995; 16: 855-860.

30) Ishikawa K, Miyamoto $\mathrm{Y}$, Takechi M, Ueyama $\mathrm{Y}$, Suzuki K, Nagayama M, Matsumura T. Effects of neutral sodium hydrogen phosphate on setting reaction and mechanical strength of hydroxyapatite putty. J Biomed Mater Res 1999; 44: 322-329.

31) Fujisawa K, Sugawara A, Kusama K, Nishiyama M, Murai S, Takagi S, Chow LC. Fluorescent labeling analysis and electron probe microanalysis for alveolar ridge augmentation using calcium phosphate cement. Dent Mater J 2002; 21: 296-305.

32) Tajima S, Nishimoto N, Kishi Y, Matsuya S, Ishikawa $\mathrm{K}$. Effects of added sodium alginate on mechanical strength of apatite cement. Dent Mater J 2004; 23: 329334.

33) Shiga $Y$, Shimogoryo R, Oka T, Matsuya S, Ishikawa $\mathrm{K}$. The effect of initial hemostatic period on the mechanical strength and transformation of apatite cement. Dent Mater J 2004; 23: 335-339.

34) Schliephake H, Neukam FW, Klosa D. Influence of pore dimensions on bone ingrowth into porous hydroxylapatite blocks used as bone graft substitutes. A histometric study. Int J Oral Maxillofac Surg 1991; 20: $53-58$.

35) Cook SD, Thongpreda N, Anderson RC, Thomas KA, Haddad RJ Jr, Griffin CD. Optimum pore size for bone cement fixation. Clin Orthop 1987; 223: 296-302.

36) Takagi S, Chow LC. Formation of macropores in calcium phosphate cement implants. J Mater Sci: Mater Med 2001; 12: 135-139.

37) Xu HHK, Quinn JB, Takagi S, Chow LC, Eichmiller FC. Strong and macroporous calcium phosphate cement: Effects of porosity and fiber reinforcement on mechanical properties. J Biomed Mater Res 2001; 57: 457-466.

38) Xu HHK, Quinn JB, Takagi S, Chow LC. Fast-setting calcium phosphate scaffolds with tailored macropore formation rates for bone regeneration. $J$ Biomed Mater Res 2004; 68A: 725-734.

39) Zhang Y, Xu HHK, Takagi S, Chow LC. In-situ hardening hydroxyapatite-based scaffold for bone repair. J Mater Sci: Mater Med 2006; 17: 437-445. 